\title{
Characterization of Fly Ash and a Protective Coating for Brazilian Thermal Power Plant Boilers
}

\author{
Diego de Lima Gomes ${ }^{a *}$ (D), Bruno Reis Cardoso ${ }^{b}$ (D), Heloisa Cunha Furtado ${ }^{\text {(D) }}$, Marilia Garcia Diniz ${ }^{a}$ (D) \\ ${ }^{a}$ Universidade do Estado do Rio de Janeiro (UERJ), Departamento de Engenharia Mecânica, Rio de \\ Janeiro, RJ, Brasil \\ ${ }^{b}$ Centro de Pesquisas de Energia Elétrica (CEPEL), Rio de Janeiro, RJ, Brasil
}

Received: June 16, 2020; Revised: October 03, 2020; Accepted: October 16, 2020

\begin{abstract}
Thermoelectric power plants that use mineral coal show high wear in heat exchanger due to the action of several damage mechanisms associated with the impact of hard particles from the residue of burnt coal, the ashes. The employment of coatings should be given into consideration particularly for critical components, which are subject to severe erosive conditions is one of the solutions. However, the choice of material will depend on several factors, including the properties of aggressive ashes. This paper aims to characterize ashes generated by a Brazilian coal-based power plant and a FeCrNbNi-based metallic coating obtained by the electric arc spraying process. No trace of sulfur content was found in fly ashes and it was defined that wear is mainly related to the impact and energy of hard particles are the leading causes of degradation in coal-fired boiler equipment. According to the assessment, applied coating showed $(5 \pm 2) \%$ by volume of pores and cracks, with $1.6 \%$ of oxides after the spraying process and hardness $35 \%$ greater than ash particles. Preliminary results in field operation suggest that the material showed relatively low wear compared to the original substrate and showed great applicability in controlling material deterioration for this purpose.
\end{abstract}

Keywords: Thermoelectric, fly ash, thermal spraying, metallic coating.

\section{Introduction}

In Brazil, electricity generation is mainly from hydroelectric power plants, representing $61 \%$ of total production. However, thermal units are still necessary as complementary energy. They operate to balance the lack of power supply during dry periods or high energy consumption. Despite recent investments in renewable energy sources, they play an important strategic role, as they represent only $2 \%$ of energy production $^{1,2}$. In thermal units that use coal as a heat source, some mechanisms can lead to surface deterioration and other carbon steel components, reducing their lifespan. As already known, the main deterioration mechanisms in power plant boilers are creep damage, microstructural degradation, erosion by fly-ash and high-temperature fatigue, embrittlement, carburization, hydrogen damage, graphitization, thermal shock, liquid metal embrittlement, and high-temperature corrosion of various types ${ }^{3-5}$. These mechanisms are associated with long-term exposure to high-temperatures, strain generated by particle's impact, and corrosive action of combustion products, which can be intensified due to high temperatures ${ }^{5,6}$. The expected service life of applied materials is 20 years for boilers operating under standard conditions. However, corrosion and various correlations between temperatures and particulate content, causing wear type changes, are the leading causes of unplanned shutdowns in power plants ${ }^{7}$. The main erosion agents are ash particles and small solid inorganic waste generated by unburned particles in fly ash ${ }^{8,9}$. One of the proposed solutions for the erosion problem is the use of materials more resistant than the aggressor agent with

*e-mail:diego.lima@uerj.br the use of protective coatings, which prevent unscheduled failures by maintenance ${ }^{10}$.

The number of water-tube boilers in thermoelectric power plants and related metallurgical situations that cause losses due to wear by particle's impact promotes research to solve the problem. In addition, environmental impact is minimized through better boiler performance ${ }^{4}$.

The reduction in unscheduled boiler shutdowns will be reflected in lower production costs and lower pollutant emissions ${ }^{11}$. Coatings can be an alternative to be used to protect these types of equipment and minimize the associated degradation effects ${ }^{12,13}$. Major commercial thermal spraying process technologies can be broadly grouped into two basic categories: those that use electrical energy and those that use chemical energy ${ }^{14}$. Thermal spraying consists of a material heating in a molten or superheated state, and these particles are accelerated to the substrate surface by a carrier gas. The arc spraying process has a high deposition rate and a lower operating cost than other similar processes and the possibility of application and maintenance in-field operation. The main mechanism of adhesion and cohesion of coating is the mechanical anchoring of the splats ${ }^{13-16}$.

However, the spraying process has an intrinsic characteristic as the presence of pores and cracks formed in the solidification process of successive semi-molten particles by the raw material used ${ }^{17-19}$, and other internal defects, such as oxide inclusions and others. Many studies have already evaluated characteristics of coatings obtained by spraying process, including porosity, metallurgical and mechanical aspects ${ }^{11,13,20}$. 
It is known that coatings for coal-fired boilers must meet the maximum of some requirements, mainly to be resistant enough against the attack of ash, which may change its characteristics according to the source materials ${ }^{17,18,21-25}$.

The requirements for applied boiler coatings are: conductivity and coefficient of thermal expansion comparable to the substrate, high resistance to corrosion and abrasion, low porosity and oxide content as possible $(<5 \%)$, as well as contamination of coating-substrate interface. The coating must also have a high adhesion strength to the substrate to ensure its use. Considering these requirements, it is known that the presence of porosity, especially interconnected ones, will promote higher corrosion rates and decrease the adhesion strength of the coating ${ }^{26,27}$.

This work aimed to analyze the ashes generated in burning process of mineral coal used as an energy source in a thermoelectric plant in Brazil and considered the principal agent of erosive wear of pipes and equipment ${ }^{28}$. Chemical, geometric, microstructural, and mechanical characteristics of ash were included. The characterization of particles determined the choice of a protective coating to be used in pipes and other parts affected by an abrasive attack of ashes. The contribution aims to complement the content available in the bibliography, which correlates properties of these particles with specific characteristics arising from Brazilian mineral coal and the abrasive effect on metallic parts in thermoelectric production. In addition, quantitative stereology applied to quantify coating defects contributes to process improvement and a better choice of materials.

The ashes were collected directly from the attack region, as well as secondary regions from a thermoelectric plant. The mineral coal from southern Brazil has fixed carbon (40\%), ashes (41\%), volatile matter (18\%), sulfur (1\%) and humidity (bal.), weight \%. In Brazilian coals, it is observed that sulfur is predominantly in pyrite $\left(\mathrm{FeS}_{2}\right)$, which has iron in its composition, which can form hematite $\left(\mathrm{Fe}_{2} \mathrm{O}_{3}\right)$ after oxidation $^{29}$.

The metallic coating was select from technical characteristics and mechanical properties of materials resistant to hightemperatures (boiler operating temperatures between 550$800^{\circ} \mathrm{C}$ ). The choice of arc spraying process was due to the possibility of producing a coating on large surfaces and field operation, which is reflected in relatively low production costs compared to other similar deposition techniques ${ }^{6,7,30}$. This work also motivates evaluating alternatives alloys to be used for the thermoelectric boiler environment to optimize the cost-benefit ratio of applicable materials, since nickelbased alloys are relatively expensive ${ }^{24}$.

\section{Experimental Method}

\subsection{Coal fly ash}

High-resolution images were obtained in a scanning electron microscope (SEM) JEOL JSM 6510-LV operating at $20 \mathrm{kV}$ equipped with an Energy Dispersive Spectroscopy (EDS) detector. The fly ash particle's average diameter was obtained through measurements made on images obtained in SEM with AxioVision Software 40V 4.8.2.0, supplied by Carl Zeiss. In this process, 403 individual particles were measured.

A granulometric distribution of fly ashes was analyzed by the sieve method, and particle size fractions, classified according to a Tyler sieve series, between 100 to 635 mesh were obtained. Preliminarily, $100 \mathrm{~g}$ of ashes were heated to $110{ }^{\circ} \mathrm{C}$ for $60 \mathrm{~min}$ by moisture removal. The ash-water system's $\mathrm{pH}$ was determined using an Omega $\mathrm{pH}$ meter, model PHH 7000 (50.08 g of ash in $250.07 \mathrm{~g}$ of tap water, with initial $\mathrm{pH}$ between 7.0 and 7.5).

Quantitative determination of chemical elements was carried out by gravimetry and atomic absorption spectrophotometry (AAS). An Agilent Technologies model 240FS AA spectrophotometer was used. The particles were still subjected to X-ray diffraction in a Panalytical X'Pert Celerator diffractometer operating at $40 \mathrm{kV}$ and $40 \mathrm{~mA}$. The scanning range $(2 \theta)$ was $10-140^{\circ}$. The measurements were performed with an angular step of $0.016^{\circ}$ and an integration time of 20 seconds, considering the PANalytical's X'Pert HighScore Database.

For microhardness (HV) measurements in individual ashes particles, a mixture of polymeric resin and fly ash particles was used. This composite was subjected to metallographic preparation techniques (sanding and polishing) so that the ash particle's cross-sections could be exposed for measurements. Twenty-five massive particles of particulate were evaluated using a PANTEC MV-1000A microdurometer, with $0.9807 \mathrm{~N}$ load and $15 \mathrm{~s}$ application time. The average surface roughness Ra after polishing was $0.7 \mu \mathrm{m}$, measured using a Mitutoyo digital roughness tester, model SurfTest - S210.

\subsection{Coating preparation}

The samples were made of FeCrNbNi-based alloy, thermally sprayed onto a low-carbon steel substrate with chemical composition and thickness similar to the ASTM A-178 grade A, originally used in boilers water wall tube ${ }^{4,31}$. The coating was deposited using a TAFA 8835 arc spraying system, manually operated, as typically worked on-site, with the following parameters: $30 \mathrm{~V}, 100 \mathrm{~A}$, distance of $100 \mathrm{~mm}, 5 \mathrm{~kg} / \mathrm{h}$ of deposition rate, and air pressure of $70 \mathrm{psi}$ as atomizing gas were used. The chemical composition of wire used to obtain the coating is shown in Table 1. Hard phases generating elements such as borides, carbides and oxides as $\mathrm{Al}_{2} \mathrm{O}_{3}$, usually are added to coating systems as $\mathrm{NiCr}$ and $\mathrm{Fe}-\mathrm{Cr}$ to provide resistance to erosion ${ }^{32}$.

The coating thickness layer was approximately $400 \mu \mathrm{m}$. The sample`s surface was previously sandblasted with $\mathrm{Al}_{2} \mathrm{O}_{3}$, particles with an average diameter between 0.8 to $1.2 \mathrm{~mm}$. This blasting promotes roughness and adequate cleaning of the substrate surface ${ }^{33}$.

Table 1. Chemical composition (wt.\%) of feedstock wire material.

\begin{tabular}{ccccccccc}
\hline Element & $\mathbf{C r}$ & $\mathbf{N b}$ & $\mathbf{N i}$ & $\mathbf{B}$ & $\mathbf{A l}$ & $\mathbf{M n}$ & $\mathbf{S i}$ & $\mathbf{F e}$ \\
\hline wt. $\%$ & 13.2 & 6.0 & 5.5 & 4.2 & 2.0 & 1.3 & 1.2 & bal. \\
\hline
\end{tabular}




\subsection{Coating characterization}

Cross-sectional samples from substrate-coating system were obtained by waterjet cutting and subjected to metallographic preparation by sanding and polishing steps with diamond pastes from 6 to $1 / 4 \mu \mathrm{m}$.

Techniques of optical microscopy (OM), SEM, EDS, Digital Image Analysis (DIA) and Vickers microhardness (HV) were used in the polished cross-sections of coating samples. OM images were obtained through a ZEISS optical microscope, model Axio Imager M1m with digital image capture system. High-resolution images and semi-quantitative chemical analysis were made using a JEOL SEM, model JSM - $6510 \mathrm{LV}$, equipped with an EDS detector at $20 \mathrm{kV}$. Microhardness measurements were performed on a PANTEC MV-1000A microdurometer, with a load of $0.9807 \mathrm{~N}$ and a $15 \mathrm{~s}$ application time. Eighteen measurements were made, forming a $6 \times 3$ grid, covering three coating regions: lower (close to the substrate), intermediate and upper (away from the substrate).

Were processed $33 \mathrm{OM}$ images with 500X magnification of cross-section samples to get porosity features in the coating by DIA. Fiji (Image J) software ${ }^{34}$ was used for the extraction of image attributes. After segmentation in binary images to separate the image objects of interest from the background, the defect fraction was calculated by the ratio of dark tones and selected square area ${ }^{35}$.

Figure 1 exemplifies one of images used and its respective histogram (left and above) generated for quantification process. In the image, the principal elements and defects of coatings obtained by arc thermal spraying were also identified: lamellar structure generated by deposition of molten and solidified droplets on the substrate surface, unmelted particles, pores, and cracks ${ }^{36,37}$.

\section{Results and Discussion}

\subsection{Coal fly ash results}

The ashes were predominantly massive and spherical, a few hollow or irregularly shaped (Figure 2a), in accordance with other studies ${ }^{38}$. The diameters calculated by DIA varied between 5 and $45 \mu \mathrm{m}$ ( $68 \%$ of analyzed particles). The granulometric distribution obtained by sieving (Figure 2b) revealed that $60 \%$ of the material was made up of particles between 60 and $90 \mu \mathrm{m}$ in diameter. Thus, the result obtained by DIA showed only finer particles of material.

EDS`s semi-quantitative elemental results revealed the presence of silicon, iron, aluminum, potassium, and calcium (Figure $2 \mathrm{c}$ ). The results of quantitative chemical analysis are in agreement, as they showed the presence essentially of silicon, iron, and aluminum, according to Table 2. In all analyses, not even traces of sulfur were found; this is considered to be strongly responsible for hot corrosion processes in steam boilers ${ }^{6,39}$. Fuels used contain impurities and often tend to form ash deposits. In particular, vanadium, sulfur, and alkali metals cause corrosion when the metal surface temperature is $580-650^{\circ} \mathrm{C}^{6,40}$. The presence of iron can be associated with a probable oxidation of pyrite and/or related to the segregation of minerals containing this element during a probable pre-treatment of coal.

The $\mathrm{pH} 9.4$ revealed a marked alkalinity. The presence of alkaline-earth oxides like magnesium oxide $(\mathrm{MgO})$ promoted the alkaline character of the ashes. The absence

Table 2. Elements in ashes (wt.\%). Results obtained by gravimetry and atomic absorption spectrophotometry.

\begin{tabular}{ccccc}
\hline $\mathbf{S i}$ & $\mathbf{F e}$ & Al & Ca & Mg \\
\hline 29.4 & 13.6 & 8.8 & 0.68 & 0.46 \\
\hline
\end{tabular}

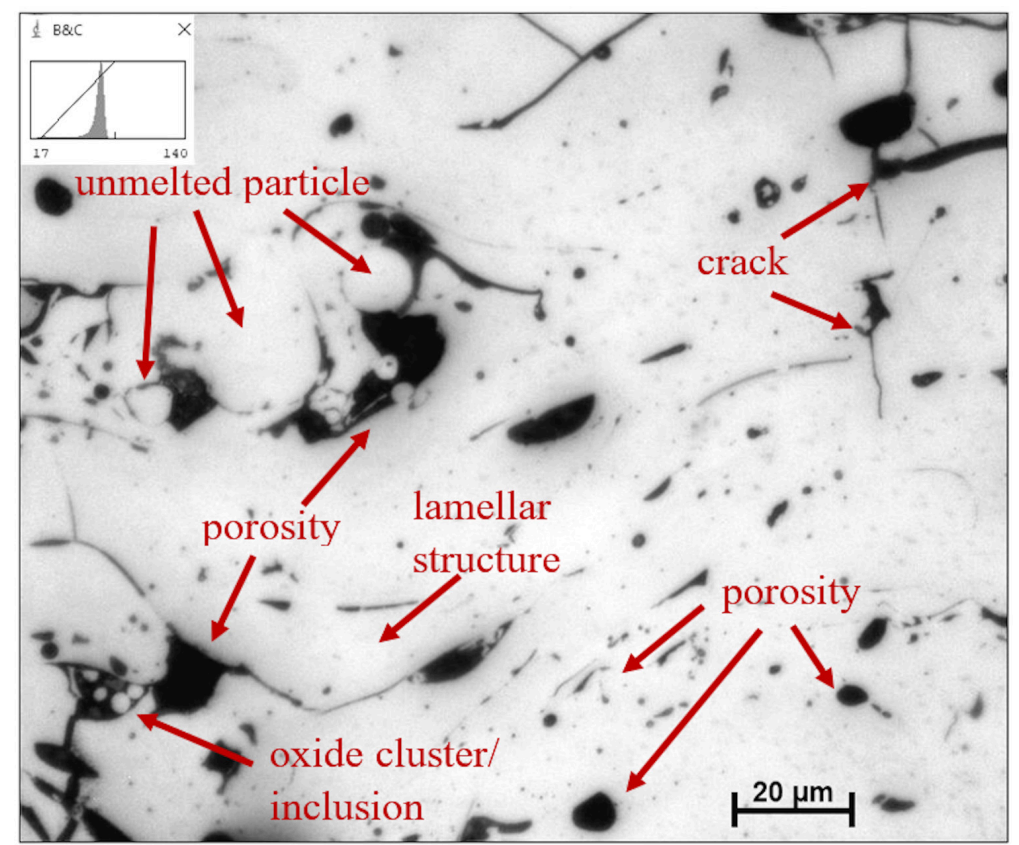

Figure 1. Coating cross-section. The dark tonal regions are pores and cracks. Unmelted particles were also observed. 


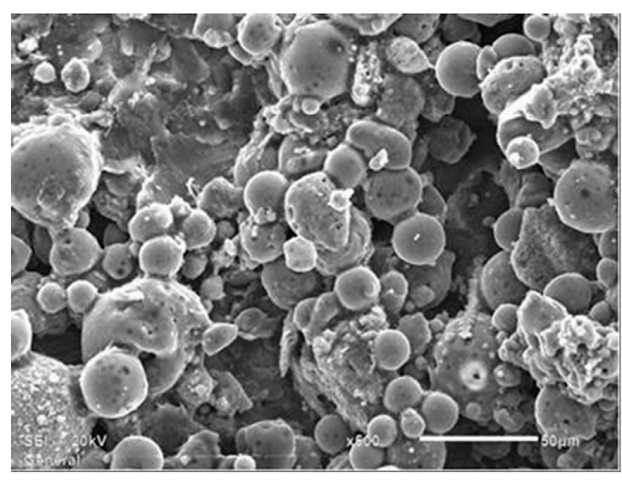

(a)

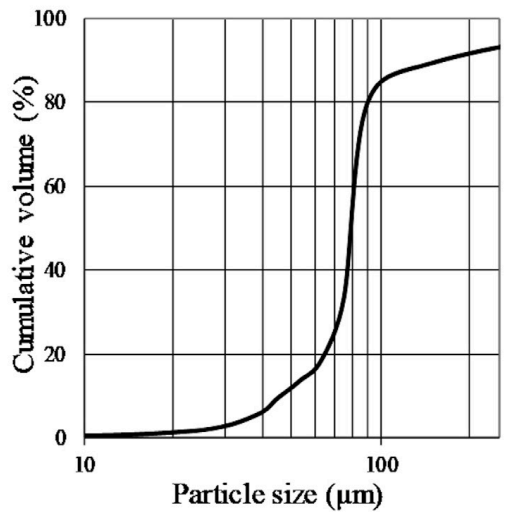

(b)

Full scale counts: 1220

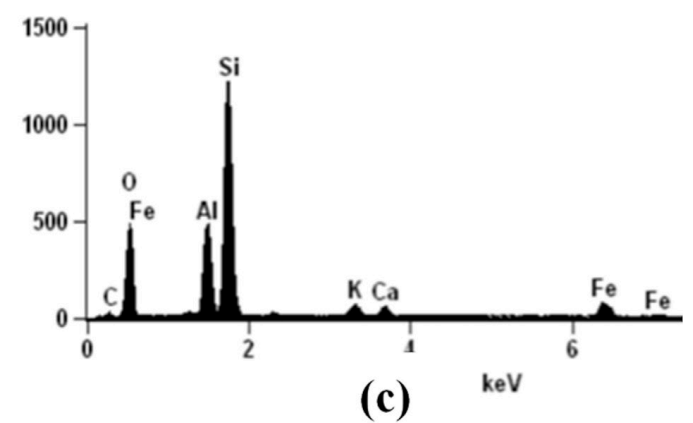

Figure 2. (a) SEM morphology of fly ashes particles; (b) Particle size distribution of Brazilian fly ash; (c) EDS spectrum of coal fly ash studied.

of sulfur led to the conclusion that the problem of boiler pipe erosion was mainly due to ash impact wear and not sulfur-associated corrosion ${ }^{39}$. Although the deleterious issues related to the presence of sulfur in ashes have been discarded, formations of $\mathrm{SO}_{3}$ in flue gas and the presence of alkali metal have not been dismissed. Therefore, the choice of the chemical composition of the alloy was considered as a possibility ${ }^{19,39,41}$.

Figure 3 exemplifies one of the many results obtained for X-ray diffraction (XRD). Phases of silicon dioxide $\left(\mathrm{SiO}_{2}\right.$ - peaks of higher intensities) and calcium aluminate $\left(\mathrm{Ca}_{2} \mathrm{Al}_{2} \mathrm{O}_{5-}\right.$ peaks of lower intensity) were identified. All analysis confirms the basic character of ashes and the absence of sulfur. The obtained results were in accordance with the literature, which essentially mentions sulfide's presence, carbonates, and quartz as the most common elements in mineral coals ${ }^{29}$.

Microhardness measurements were made on various solid particles of ashes. Figure 4 exemplifies a mark generated by Vickers penetrator on a particle embedded in resin. Only hardness values were found in literature for sintered ash briquettes or hard materials such as quartz, alumina, or silicon carbide, whose values differ from individual ash particles` hardness ${ }^{42,43}$.

The average microhardness was $(825 \pm 155) \mathrm{HV}_{0.1}$. The dispersion was due to internal porosity in some particles, as well as the variety of existing oxides. The value found was close to silica (quartz), with a hardness of about $800 \mathrm{HV}^{44}$.

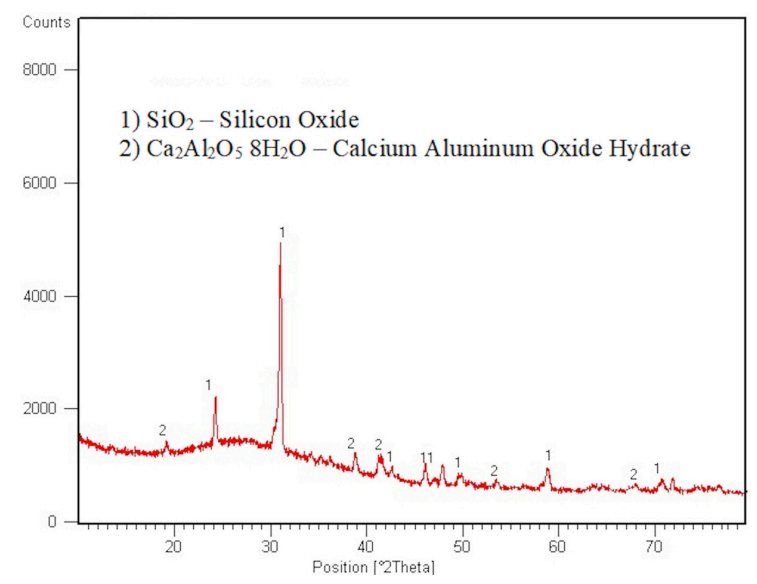

Figure 3. XRD patterns of fly ash sample.

\subsection{Coating characterization}

The micrographic aspects obtained from OM revealed the presence of regular layers that follow the substrate profile. This aspect was already expected since the impact of fused particles that solidify on the coated surface generates this aspect, being typical of the arc spraying process (Figure 5) $)^{37}$. The average coating thickness was $(410 \pm 36) \mu \mathrm{m}$.

The substrate's surface preparation by blasting may have added some alumina at the substrate-coating interface. This contamination can affect the adhesion performance of the 


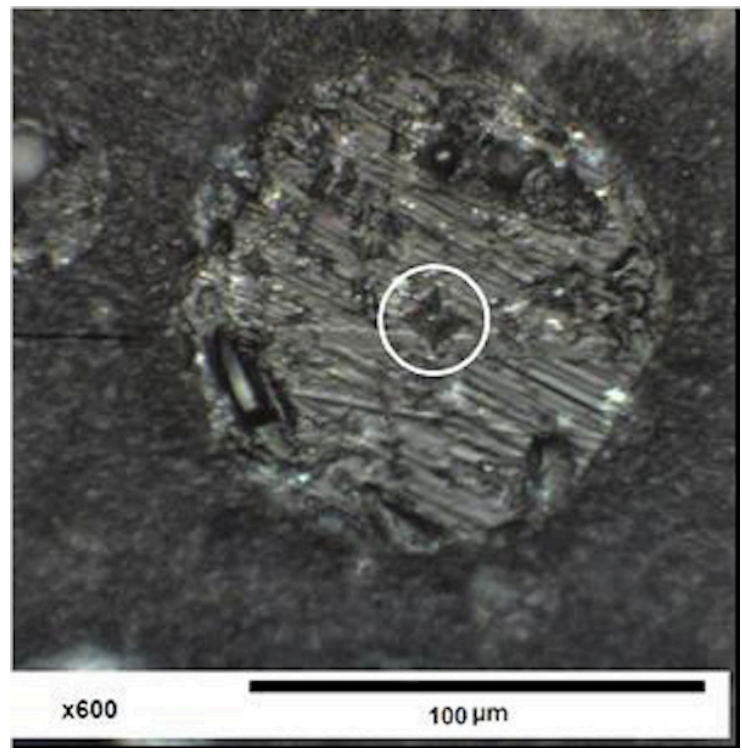

Figure 4. Cross-section of coal ash particle with Vickers microhardness penetration identification.

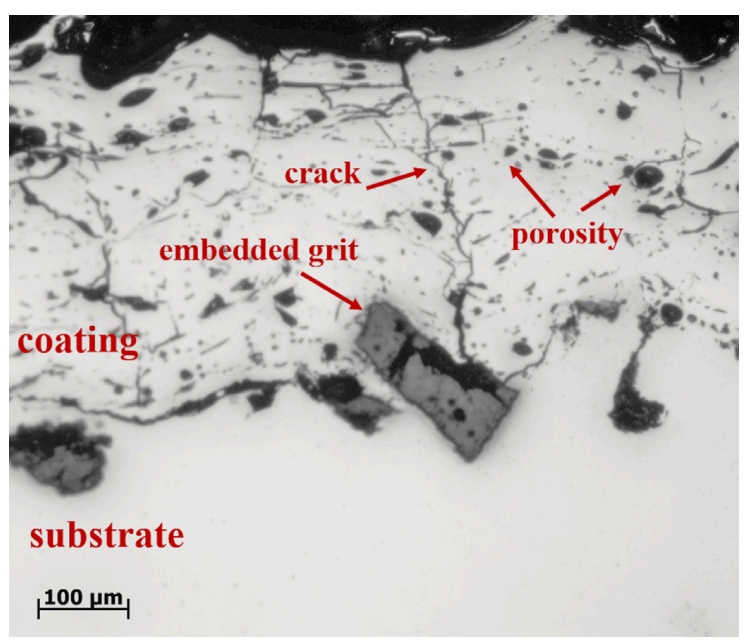

Figure 5. Coating cross-section on the substrate. OM, 100X. The presence of alumina used for surface preparation could be observed at the coating-substrate interface.

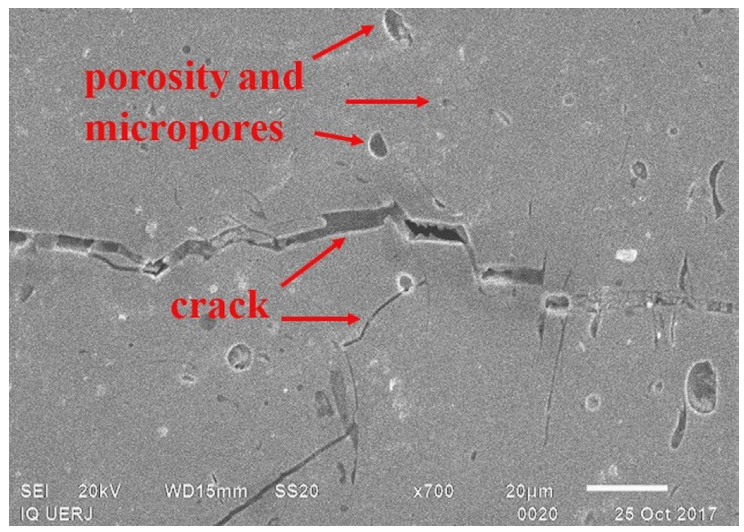

Figure 6. Coating cross-section. SEM, 700X. Cracks and pores (regions with more intense shades of gray) are defects typically associated with the spraying process used. coating to the substrate. However, this parameter was not evaluated in this work.

Cracks and pores associated with coatings obtained by arc thermal spraying were also observed by SEM (Figure 6). Among the deposited metallic layers, some oxides were identified, which was expected, due to the oxidation of some elements with greater chemical activity and oxygen affinity in the deposited alloy ${ }^{45-47}$.

Moreover, the presence of interconnected pores and cracks can reduce corrosion resistance's effectiveness, especially when this factor promotes the exposure of the substrate to some active electrolyte. In addition, the presence of pores and cracks can mean fewer points of contact and cohesion between layers coating and places for possible nucleation and corrosion processes ${ }^{41,45,48}$.

The volumetric fraction ( $\mathrm{Vv}$ ) of defects in coating, including cracks and pores by DIA for OM images, was $(5 \pm 2) \%$. DIA was also performed for images obtained by EDS mapping to present elements more reactive when presence of oxygen. These regions contained high concentrations of aluminum $(\mathrm{Vv}=1.4 \%)$ and silicon $(\mathrm{Vv}=0.2 \%)$ formed between layers or concentrated in points of metallic matrix, as exemplified in Figure $7^{49,50}$.

There was a predominance of elongated defects (4\%), that is, cracks with a shape factor of less than $0.7^{51,52}$. The value obtained for $\mathrm{Vv}$ of cracks and pores was within the expected porosity values for arc thermal spraying (between $2 \%$ and $14 \%)^{7,53-55}$. The smaller the presence of pores and cracks, the greater the cohesion between layers and the lower the residual stress in the coating ${ }^{13,48}$

The chemical composition determined by EDS of sprayed alloy was as indicated by the manufacturer for the wires used (Table 1), where the significant presence of $\mathrm{Fe}, \mathrm{Cr}, \mathrm{Nb}$, $\mathrm{Ni}, \mathrm{B}, \mathrm{Al}, \mathrm{Mn}$ and $\mathrm{Si}$ was identified. Figure 8 exemplifies a qualitative microanalysis (spectrum) obtained in one of the several coating regions analyzed by EDS. Chemical reactions, such as metal alloy oxidation during heating, can change chemical compositions and phases of sprayed materials and modify coating's funtions ${ }^{56}$.

Microhardness measurements showed local variations in this property, most likely due to the presence of contaminating oxides, cracks, pores, and thermal gradients between layers sprayed during the process. Figure 9 shows a mapping of microhardness in the cross-section of the studied coating. According to the literature, hardness for coatings must be $20 \%$ higher than erosive particles resulting in a minimized erosion rate ${ }^{44}$. Although hardness is only one of the many desirable properties to mitigate erosion of water wall panels, it is one of the most important properties for wear protection against particle impact.

Analysis in high hardness coatings requires greater care than conventional ones. Surfaces can be influenced by the preparation, also by hardening generated by material hardenability. The quality and durability of coatings can be improved by parameter optimization of the spraying process, preparation of substrate surface for better adhesion, and automation of the process ${ }^{27}$. In addition, the melting conditions and structure of coatings by electric arc spraying depending on the pressure of spraying airflow, spraying angle, speed, work distance, and others, which can result 
Revest A Mag: 600 Acc. Voltage: $20.0 \mathrm{kV}$

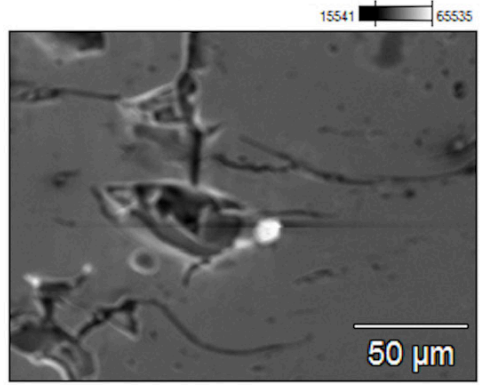

(a)

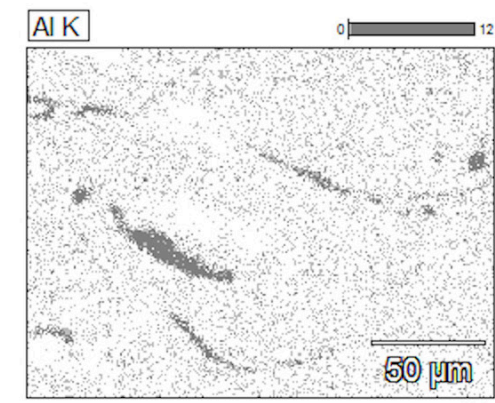

(b)

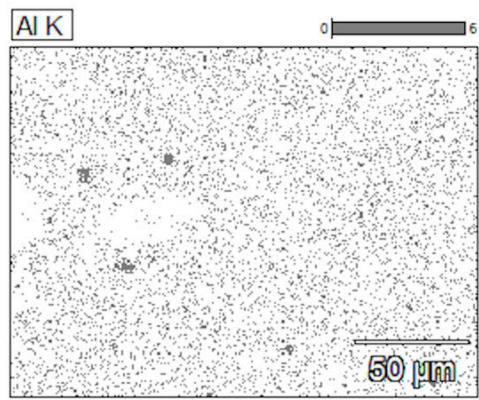

(e)

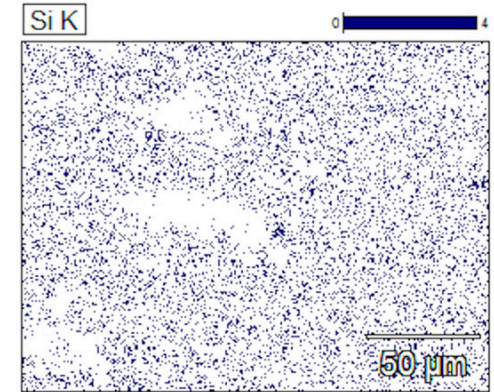

(c)

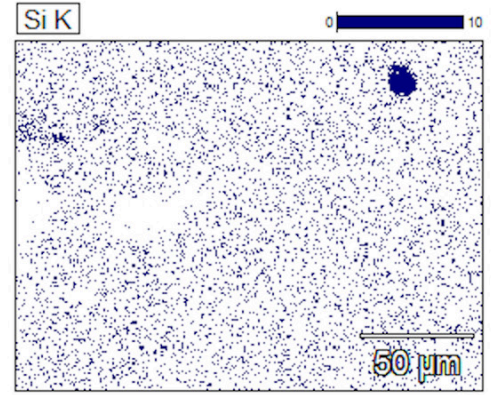

(f)

Figure 7. EDS mapping showing the predominant regions of $\mathrm{Al}$ and $\mathrm{Si}$ where oxides of these elements were probably formed.

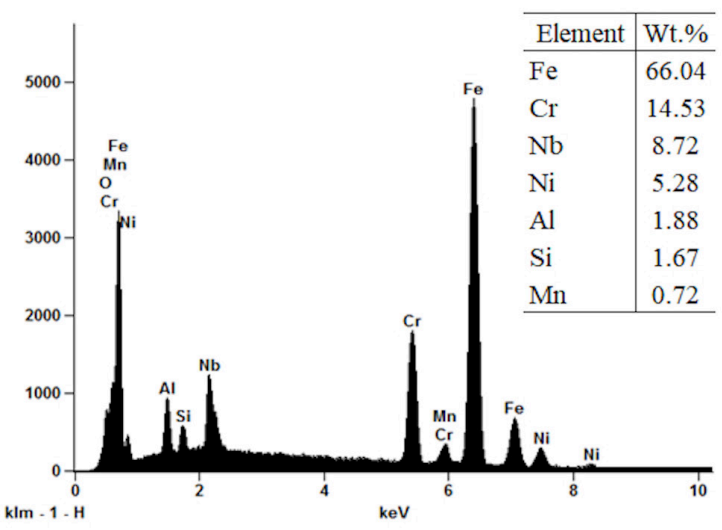

Figure 8. Spectrum features of energy to the elements in coating. Significant presence of $\mathrm{Fe}, \mathrm{Cr}, \mathrm{Nb}, \mathrm{Ni}, \mathrm{Al}, \mathrm{Mn}$ and $\mathrm{Si}$, in a semiquantitative method, the elements being in accordance with wires used.

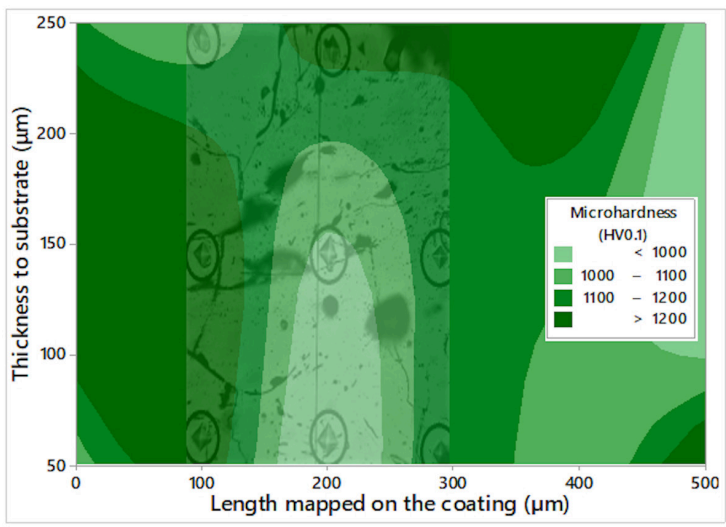

Figure 9. Microhardness mapping of coating cross-section. in controlling the amount of the oxide phase and porosity in coatings, and mechanical characteristics like hardness, residual tensile stresses, cohesion and adhesion ${ }^{13,15}$.

It should be noted the ability of coatings to protect the substrate against wear depends not only on the composition and microstructure of coating but also on its physical and mechanical properties, which relates the choice of starting material, the type and control of processing and energy source used.

\section{Conclusions}

The ashes particles generated by Brazilian mineral coal used in boilers of thermoelectric plants presented a predominantly spherical morphological aspect with a higher frequency of particles (56 wt.\%) for granulometric range between 75 and $90 \mu \mathrm{m}$, being essentially a combination of alumina, silica and iron oxide, of an alkaline character in terms of $\mathrm{pH}$. No trace of sulfur was found in the ashes, which was previously considered to be strongly responsible for hot corrosion processes in boilers. The average microhardness was $825 \mathrm{HV}_{0.1}$, and similar to quartz. This high hardness and absence of sulfur led to the conclusion that the problem of erosion is mainly caused by impact of ashes in different parts of boiler tubes.

In relation to the metallic coating proposed to cover the parts most impacted by fly ash, the volumetric fraction of cracks and pores was $(5 \pm 2) \%$. The coating showed $1.4 \%$ aluminum oxides and $0.2 \%$ silicon oxides dispersed by metallic matrix. These values are within the expected for metallic coatings obtained by arc spraying process. The average microhardness value of the coating was $(1,115 \pm 130) \mathrm{HV}_{0.1}$, or $437 \%$ higher than the carbon steel substrate used $\left(255 \mathrm{HV}_{0.1}\right)$, 
which was similar to the steel used in the boiler pipes and $35 \%$ higher than the fly ashes $\left(825 \mathrm{HV}_{0.1}\right)$. Coated samples were placed inside the boiler and returned intact after a one-year test, despite thermophysical differences between the coating and the substrate. As a preliminary result, the technical solution's effectiveness is being evaluated, added to other tests, such as evaluation of abrasion wear, resistance to adhesion, complementary thermal analysis, and others. This result can lead to a lower wear rate for pipes that are coated on-site, compared to the original substrate used without any protection.

The technique of arc spraying was considered promising to be used in Brazilian thermal power plant boilers, given protection of carbon steel tubes and equipment susceptible to high friction wear and ash impact, and also due to their greater practicality of field application and lower cost as compared with other spraying techniques for application of advanced surface coatings.

\section{Acknowledgements}

This study was financed in part by the Coordenação de Aperfeiçoamento de Pessoal de Nível Superior - Brasil (CAPES) - Finance Code 001.

The authors would like to thanks to Maurício Leonardo Torem, José Roberto Moraes d'Almeida (PUC-Rio), and Guilherme Bungner (VGK).

\section{References}

1. Leal FI, Rego EE, Ribeiro CO. Levelized cost analysis of thermoelectric generation in Brazil: a comparative economic and policy study with environmental implications. J Nat Gas Sci Eng. 2017;44:191-201. http://dx.doi.org/10.1016/j. jngse.2017.04.017.

2. Zurn HH, Tenfen D, Rolim JG, Richter A, Hauer I. Electrical energy demand efficiency efforts in Brazil, past, lessons learned, present and future: a critical review. Renew Sustain Energy Rev. 2017;67:1081-6. http://dx.doi.org/10.1016/j.rser.2016.09.037.

3. Furtado HC, May IL. High temperature degradation in power plants and refineries. Mater Res. 2004;7:103-10. http://dx.doi. org/10.1590/S1516-14392004000100015.

4. Cardoso BR, Comeli FW, Santana RM, Furtado HC, Lisboa MB, Almeida LH. Microstructural degradation of boiler tubes due to the presence of internal oxide layer. J Mater Res Technol. 2012;1:109-16. http://dx.doi.org/10.1016/S2238-7854(12)700200 .

5. Furtado HC, Felippe L, Silveira TL, Pascual R, May IL. Problems with aging vessels in high temperature plant. Procedia Eng. 2015;130:1470-7. http://dx.doi.org/10.1016/j.proeng.2015.12.315.

6. Kumar S, Kumar M, Handa A. Combating hot corrosion of boiler tubes - A study. Eng Fail Anal. 2018;94:379-95. http:// dx.doi.org/10.1016/j.engfailanal.2018.08.004.

7. Yury K, Filippov M, Makarov A, Malygina I, Soboleva N, Fantozzi D, et al. Arc-sprayed Fe-based coatings from cored wires for wear and corrosion protection in power engineering. Coatings. 2018;8:71. http://dx.doi.org/10.3390/coatings8020071.

8. Cheng JB, Liang XB, Chen YX, Wang ZH, Xu BS. Hightemperature erosion resistance of $\mathrm{FeBSiNb}$ amorphous coatings deposited by Arc spraying for boiler applications. J Therm Spray Technol. 2013;22:820-7. http://dx.doi.org/10.1007/ s11666-012-9876-5.

9. Saha A. Boiler tube failures. In: Makhlouf ASH, Aliofkhazraei M, editors. Handbook of materials failure analysis with case studies from the chemicals, concrete and power industries.
USA: Elsevier. https://doi.org/10.1016/B978-0-08-1001165.00003-X.

10. Bala N, Singh H, Prakash S. Performance of cold sprayed Ni based coatings in actual boiler environment. Surf Coat Tech. 2017;318:50-61. http://dx.doi.org/10.1016/j.surfcoat.2016.11.075

11. Wielage B, Pokhmurska H, Student M, Gvozdeckii V, Stupnyckyj T. Iron-based coatings arc-sprayed with cored wires for applications at elevated temperatures. Surf Coat Tech. 2013;220:27-35. http://dx.doi.org/10.1016/j.surfcoat.2012.12.013.

12. Szymański K, Hernas A, Moskal G, Myalska H. Thermally sprayed coatings resistant to erosion and corrosion for power plant boilers - A review. Surf Coat Tech. 2015;268:153-64. http://dx.doi.org/10.1016/j.surfcoat.2014.10.046.

13. Student M, Gvozdetsky V, Student O, Prentkovskis O, Maruschak $\mathrm{P}$, Olenyuk $\mathrm{O}$, Titova $\mathrm{L}$ The effect of increasing the air flow pressure on the properties of coatings during the arc spraying of cored wires. Strojnícky časopis - Journal of Mechanical Engineering. 2019;69(4):133-46. https://doi.org/10.2478/ scjme-2019-0048.

14. Smith MF. Comparing cold spray with thermal spray coating technologies. In: Champagne VK. The cold spray materials deposition process: fundamentals and apllications. USA: Elsevier; 2007. https://doi.org/10.1533/9781845693787.1.43.

15. Sucharski GB, Pukasiewicz AGM, Váz RF, Paredes RSC. Optimization of the deposition parameters of HVOF $\mathrm{FeMnCrSi}+\mathrm{Ni}+\mathrm{B}$ thermally sprayed coatings. Soldag Insp. 2015;20:238-52. http://dx.doi.org/10.1590/0104-9224/SI2002.11.

16. Tucker RC Jr. Thermal spray technology. Materials Park: ASM International; 2013. Introduction to thermal spray technology. https://doi.org/10.31399/asm.hb.v05a.a0005706.

17. Wang Y, Gauvin R, Kong M, Lin C, Liu Z, Zeng Y. Panoramic statistics on porosity and microstructural features of plasma sprayed Y 2 O 3 -ZrO 2 thermal barrier coatings. Surf Coat Tech. 2017;316:239-45. http://dx.doi.org/10.1016/j.surfcoat.2017.03.030.

18. Wang Y, Sun C, Sun J, Zhao W, Dong L, Li L, Meng F. Erosion behavior of arc sprayed $\mathrm{FeTi} / \mathrm{CrB}$ MMC coating at elevated temperature. Surf Coat Tech. 2015;262:141-7. http://dx.doi. org/10.1016/j.surfcoat.2014.12.027.

19. Matthews S, James B, Hyland M. High temperature erosionoxidation of $\mathrm{Cr} 3 \mathrm{C} 2-\mathrm{NiCr}$ thermal spray coatings under simulated turbine conditions. Corros Sci. 2013;70:203-11. http://dx.doi. org/10.1016/j.corsci.2013.01.030.

20. Guzanová A, Brezinová J, Draganovská D, Maruschak PO. Properties of coatings created by HVOF technology using microand nano-sized powder. Koroze a Ochr Mater. 2019;63:86-93. http://dx.doi.org/10.2478/kom-2019-0011.

21. Lawrence M, Jiang Y. Porosity, pore size distribution, microstructure. In S. Amziane, F. Collet (Eds.), Bio-aggregates based building materials (Vol. 23, RILEM State-of-the-Art Reports). Dordrecht: Springer. https://doi.org/10.1007/978-94-024-1031$0 \_2$.

22. Zeng C, Tian W, Liao WH, Hua L. Microstructure and porosity evaluation in laser-cladding deposited Ni-based coatings. Surf Coat Tech. 2016;294:122-30. http://dx.doi.org/10.1016/j. surfcoat.2016.03.083.

23. Zhang XC, Xu BS, Xuan FZ, Wang HD, Wu YX, Tu ST. Statistical analyses of porosity variations in plasma-sprayed Ni-based coatings. J Alloys Compd. 2009;467:501-8. http:// dx.doi.org/10.1016/j.jallcom.2007.12.083.

24. Vicenzi J, Villanova DL, Lima MD, Takimi AS, Marques CM, Bergmann CP. HVOF-coatings against high temperature erosion $\left(\sim 300{ }^{\circ} \mathrm{C}\right)$ by coal fly ash in thermoelectric power plant. Mater Des. 2006;27:236-42. http://dx.doi.org/10.1016/j. matdes.2004.10.008.

25. Du H, Shin JH, Lee SW. Study on porosity of plasma-sprayed coatings by digital image analysis method. J Therm Spray Technol. 2005;14:453-61. http://dx.doi.org/10.1361/105996305X76450. 
26. Li R, He DY, Zhou Z, Zhao LD, Song XY. High temperature corrosion behaviour of wire arc sprayed Fe based coatings. Surf Eng. 2014;30:573-8. http://dx.doi.org/10.1179/1743294 414Y.0000000287.

27. Richman RH, Cheruvu NS. Program on technology innovation: state of knowledge review of nanostructured coatings for boiler tube applications (TR 1014805). California: Electric Power Research Institute; 2007.

28. Gomes DL. Caracterização de cinzas leves e de revestimento para caldeiras de central termelétrica brasileira. [dissertação] Rio de Janeiro (RJ): Universidade do Estado do Rio de Janeiro; 2018.

29. Fallavena VLV, Abreu CS, Inácio TD, Pires M, Azevedo CMN, Fernandes ID, Ferret LS, Tarazona MRM. Caracterização detalhada de material de referência certificado de carvão brasileiro. Quim Nova. 2013;36:859-64. http://dx.doi.org/10.1590/ S0100-40422013000600020.

30. Galedari SA, Mahdavi A, Azarmi F, Huang Y, McDonald A. A comprehensive review of corrosion resistance of thermallysprayed and thermally-diffused protective coatings on steel structures. J Therm Spray Technol. 2019;28:645-77. http:// dx.doi.org/10.1007/s11666-019-00855-3.

31. ASTM International. ASTM A178-19. Standard Specification for Electric-Resistance-Welded Carbon Steel and Carbon-Manganese Steel Boiler and Superheater Tubes. West Conshohocken (PA): ASTM International; 2019. https://doi.org/10.1520/ A0178_A0178M-19.

32. Baker W. Materials solutions for waterwall wastage - an update (TR 1009618) [Internet]. USA: EPRI; 2005. [cited 2020 Oct 16]. Available from: https://www.epri.com/research/ products/1009618

33. Kromer R, Costil S, Verdy C, Gojon S, Liao H. Laser surface texturing to enhance adhesion bond strength of spray coatings - Cold spraying, wire-arc spraying, and atmospheric plasma spraying. Surf Coat Tech. 2018;352:642-53. http://dx.doi. org/10.1016/j.surfcoat.2017.05.007.

34. Image J. Image J Software. Image Processing and Analysis in Java [Internet]. Image J; 2020 [cited 2020 Oct 16]. Available from: https://imagej.nih.gov/ij/

35. Paciornik S, Mauricio MHP. Digital imaging. In: Vander Voort GF, editor. Metallography and microstructures. Ohio: ASM International; 2004. https://doi.org/10.31399/asm.hb.v09. a0003757.

36. Antou G, Montavon G, Hlawka F, Cornet A, Coddet C. Characterizations of the pore-crack network architecture of thermal-sprayed coatings. Mater Charact. 2004;53:361-72. http://dx.doi.org/10.1016/j.matchar.2004.08.015.

37. Crawmer DE. Coating structures, properties, and materials. In: Tucker Jr RC, editor. Handbook of thermal spray technology. West Conshohocken: ASM International; 2013. https://doi. org/10.31399/asm.hb.v05a.a0005755.

38. van der Merwe EM, Prinsloo LC, Mathebula CL, Swart HC, Coetsee E, Doucet FJ. Surface and bulk characterization of an ultrafine South African coal fly ash with reference to polymer applications. Appl Surf Sci. 2014;317:73-83. http://dx.doi. org/10.1016/j.apsusc.2014.08.080.

39. Xiang B, Shen W, Zhang M, Yang H, Lu J. Effects of different factors on sulfur trioxide formations in a coal-fired circulating fluidized bed boiler. Chem Eng Sci. 2017;172:262-77. http:// dx.doi.org/10.1016/j.ces.2017.05.049.

40. Caillat S, Vakkilainen E. Large-scale biomass combustion plants: an overview. In: Rosendahl L, editor. Biomass combustion science, technology and engineering. USA: Elsevier. https:// doi.org/10.1533/9780857097439.3.189.

41. Fonseca GS, de Oliveira PM, Diniz MG, Bubnoff DV, Castro JA. Sigma phase in superduplex stainless steel: formation, kinetics and microstructural path. Mater Res. 2017;20:249-55. http://dx.doi.org/10.1590/1980-5373-mr-2016-0436.

42. Kumar S, Singh SK, Mishra SC. Processing and characterization of fly-ash compacts. Mater Today Proc. 2018;5:3396-402. http:// dx.doi.org/10.1016/j.matpr.2017.11.584.

43. Desale GR, Gandhi BK, Jain SC. Effect of erodent properties on erosion wear of ductile type materials. Wear. 2006;261:914-21. http://dx.doi.org/10.1016/j.wear.2006.01.035.

44. Hutchings I, Shipway P. Tribology. 2nd ed. USA: Elsevier; 2017. p. 165-236. Wear by hard particles. https://doi.org/10.1016/ B978-0-08-100910-9.00006-4.

45. Xu YX, Lu JT, Li WY, Yang XW. Oxidation behaviour of Nbrich $\mathrm{Ni}-\mathrm{Cr}-\mathrm{Fe}$ alloys: role and effect of carbides precipitates. Corros Sci. 2018;140:252-9. http://dx.doi.org/10.1016/j. corsci.2018.05.040.

46. Tian H, Wang C, Guo M, Tang Z, Wei S, Xu B. Phase composition and formation mechanisms of a high-velocity electric arc-sprayed FeNiCrAl coating. J Alloys Compd. 2018;769:998-1006. http:// dx.doi.org/10.1016/j.jallcom.2018.08.070.

47. Wei Q, Yin Z, Li H. Oxidation control in plasma spraying NiCrCoAlY coating. Appl Surf Sci. 2012;258:5094-9. http:// dx.doi.org/10.1016/j.apsusc.2012.01.134.

48. Odhiambo JG, Li W, Zhao Y, Li CL. Porosity and its significance in plasma-sprayed coatings. Coatings. 2019;9:460. http://dx.doi. org/10.3390/coatings 9070460 .

49. Gaskell DR, Laughlin DE. Introduction to the thermodynamics of materials. Boca Raton: CRC Press; 2017.

50. Lawrence SD, Robert WG. Physical chemistry of metals. New Delhi: CBS Publishers \& Distributors Pvt. Ltd; 2002.

51. Mohan A, Poobal S. Crack detection using image processing: a critical review and analysis. Alexandria Eng J. 2018;57:787-98. http://dx.doi.org/10.1016/j.aej.2017.01.020.

52. Mat Salleh M, Magniez K, Pang S, Dormanns JW, Staiger MP. Parametric optimization of the processing of all-cellulose composite laminae. Adv Manuf Polym Compos Sci. 2017;3:739. http://dx.doi.org/10.1080/20550340.2017.1324351.

53. Majewski D, Hejwowski T, Łukasik D. The influence of microstructure of arc sprayed coatings on wear resistance. Adv Sci Technol Res J. 2018;12:285-92. http://dx.doi. org/10.12913/22998624/86210.

54. Matthews S, Schweizer M. Optimization of arc-sprayed Ni-Cr-Ti coatings for high temperature corrosion applications. J Therm Spray Technol. 2013;22:538-50. http://dx.doi.org/10.1007/ s11666-013-9914-y.

55. Deshpande S, Sampath S, Zhang H. Mechanisms of oxidation and its role in microstructural evolution of metallic thermal spray coatings-Case study for Ni-Al. Surf Coat Tech. 2006;200:5395406. http://dx.doi.org/10.1016/j.surfcoat.2005.07.072.

56. Li CJ. Thermal spraying of light alloys. In: Dong H, editor. Surface engineering of light alloys. USA: Elsevier. https://doi. org/10.1533/9781845699451.2.184. 